\title{
Retrospective Evaluation of Cases with Cow's Milk Allergy
}

\author{
İnek Sütü Alerjisi Olan Olguların Retrospektif Olarak \\ Değerlendirilmesi
}

Hülya Poyraz Efe (0000-0002-2226-7035), Yakup Canitez (0000-0001-8929-679X), Nihat Sapan (0000-0002-7601-8392)

Bursa Uludağ University Faculty of Medicine, Department of Pediatric Allergy, Bursa, Turkey

Keywords

Cow's milk allergy, prognosis, tolerance, child

\begin{abstract}
Anahtar kelimeler
İnek sütü alerjisi, prognoz, tolerans, çocuk
\end{abstract}

Received/Geliş Tarihi : 14/07/2021

Accepted/Kabul Tarihi : 10/11/2021

DOI: $10.4274 /$ jcp.2021.55477

Address for Correspondence/Yazışma Adresi: Hülya Poyraz Efe, Bursa Uludağ University Faculty of Medicine, Department of Pediatric Allergy, Bursa, Turkey

E-mail: hulyapoyraz@yahoo.com

\begin{abstract}
Introduction: Cow's milk allergy (CMA) is described as immunological reaction against to one or more milk proteins. It is known that CMA which affects about $1-3 \%$ of the general population is the most commonly seen food allergy in infants and children. It is well known that a tolerance develops and prognosis is better during the first three years of the life. In the present study, we aimed to investigate the natural course of cases diagnosed with CMA and to determine the factors which have impact on the tolerance development.

Materials and Methods: Medical records of cases who have been followed for CMA were retrospectively reviewed. Gender, age at first symptom, breastfeeding duration, family atopy history, multiple food allergies, concomitant allergic diseases, inhalant allergy sensitivity and clinical manifestation of cases were assessed. Also, prick test results, milk-specific $\operatorname{IgE}$, casein-specific $\operatorname{IgE}$ and the reactions that developed during food challenge test were evaluated.

Results: The age at first symptom was mean $4 \pm 2,3$ months. Twenty-two percent of patients had a positive family history of atopy and $30 \%$ had multiple food allergies. There were concomitant allergic disorders in $58 \%$ of patients. Skin $(93.8 \%)$, gastrointestinal system (GIS) $(24.7 \%)$ and respiratory system (18.5\%) symptoms were most commonly seen. The percentage of tolerance development by the years was determined as $41 \%$ for the first year, $64 \%$ for the second year and $75 \%$ for the third year. Milk-specific IgE level at the time of diagnosis $(\mathrm{p}=0.010)$ and asthma presence $(\mathrm{p}=0.010)$ were found significant risk factors for persistent CMA. Conclusion: Clinical parameters and allergy tests may help to predict the prognosis of CMA. Milk-specific IgE level at the time of diagnosis is the risk factor for persistent CMA.

\section{$\ddot{\mathrm{O} z}$}

Giriş: İnek sütü alerjisi (İSA) bir ya da daha fazla süt proteinine karşı oluşan immünolojik reaksiyon olarak tanımlanır. Bebekler ve çocuklarda en sık görülen besin alerjisi olup, genel populasyonun \%1-3'ünü etkilemektedir. Hayatın ilk üç yılında genellikle tolerans geliştiği ve prognozun iyi olduğu bildirilmektedir. Çalışmamızda İSA tanısı almış hastaların doğal seyrinin araştırılması ve tolerans gelişimine etki eden faktörlerin belirlenmesi amaçlandı.

Gereç ve Yöntem: Çalışma İSA tanısı ile takip edilen olguların dosyalarının geriye dönük taranarak değerlendirilmesi ile yapıldı. Hastaların cinsiyetleri, ilk semptom yaşı, anne sütü alma süresi, ailede atopi öyküsü, çoklu besin alerjisi, ek alerjik hastalık varlığı, inhalen alerjen duyarlılığı ve klinik bulguları belirlendi. Hastaların prik test sonuçları, süt spesifik IgE ve kazein spesifik IgE düzeyleri ve tolerans gelişimi üzerine olan etkileri değerlendirildi.
\end{abstract}


Bulgular: Hastaların ilk semptom yaşı ortalama 4₫2,3 aydı. Hastaların $\% 22$ 'sinde ailede atopi öyküsü ve $\% 30$ 'unda çoklu besin alerjisi mevcuttu. Hastaların \%58'inde ek alerjik hastalık vardı. Hastalarda görülen en sık semptom, \%93,8 cilt bulguları, \%24,7 GİS bulguları ve \%18,5 solunum sistemi bulgularıydı. Hastaların yıllara göre tolerans geliştirme oranları; ilk yılda \%41, ikinci yılda $\% 64$, üçüncü yılda \%75 olarak bulundu. Tanı anında yüksek süt spesifik IgE düzeyi $(\mathrm{p}=0,010)$ ve astım varlığı $(\mathrm{p}=0,010)$ persistan İSA için risk faktörü olarak belirlendi.

Sonuç: Klinik parametreler ve alerji testleri İSA'da prognozun berlilenmesinde yardımcı olabilir. Tanı anındaki süt spesifik IgE yüksekliği persistan İSA için risk faktörüdür.

\section{Introduction}

Cow's milk allergy (CMA) is described as an immunological reaction against one or more milk proteins (1). Cow's milk is the first outsider protein involved in the diet of newborns. It is known that CMA which affects about $1-3 \%$ of the general population is the most commonly seen food allergy in infants and children (1-3).

In patients with CMA, manifestations vary based on the immunological mechanism (4). Based on the underlying immunopathology, reactions are classified as follows; 1- IgE-mediated, 2- mixed $\operatorname{IgE}$ and nonIgE-mediated and 3- non-IgE-mediated (5).

In general, allergic diseases emerge during a chronological course which also described as an allergic march (6). Cow's milk allergy is the first seen clinical form of atopy. Children with CMA have a risk for the development of atopic dermatitis in the early period and asthma, allergic rhinitis and inhalant allergen sensitivity in the forthcoming years. It is known that most patients acquire tolerance up to 3 years, and the prognosis is better $(2,7)$. In the previous studies, the natural course of CMA and factors which have an effect on the prognosis were investigated, but variable results have been reported.

In the present study, demographics, clinical manifestations, skin prick test results, foodspecific IgE levels of cases diagnosed with CMA were retrospectively analyzed. This study aimed to investigate the natural course of the disease and to determine the factors which affect the tolerance development.

\section{Materials and Methos}

This study was performed reviewing the medical records of patients diagnosed with CMA between August 2011 and August 2014. Ethics committee approval was obtained from Bursa Uludag University Local Ethics Committee.
Study Sample: CMA was diagnosed based on clinic history, allergy tests, elimination of cow's milk from diet and oral food challenge test. Non-IgE-mediated CMA was diagnosed if symptoms disappear following the elimination of cow's milk from diet and reappear the following feeding by cow's milk as well as related clinic symptom presence. Data including gender, age at first symptom, breastfeeding duration, the age of the starting of complementary foods, family history of atopy, multiple food allergies, concomitant disease presence, inhalant allergen sensitivity, clinical manifestations, type of the milk protein intake were evaluated by medical chart review. Additionally, the results of the prick test and the levels of total IgE, milkand casein-specific IgE were assessed. Tolerance was defined by a negative open CM challenge followed by regular consumption of an age-appropriate quantity of $\mathrm{CM}$ at home, without any symptoms.

\section{Laboratory Methods}

Skin Prick Testing (SPT): Sensitivity against to inhalant allergens (Dermatophagoides pteronyssinus and fariena, Alternaria, pollen mixture), to foods (milk, egg, peanut) and to latex were evaluated by prick testing method. The reaction was considered positive when the mean induration diameter was at least $3 \mathrm{~mm}$ greater than that of the negative control. Diagnostic reliability of prick test for cow's milk was $\geq 8 \mathrm{~mm}$ for children under the age of 2 and of $\geq 6 \mathrm{~mm}$ for children above the age of 2 .

Total IgE Measurement: Total IgE level was measured by a chemiluminescent method using Immulite 2000 (Siemens) equipment and results were presented as kU/L. Results above the age-specific normal range were established to be high (8).

Food-Specific IgE Measurement: Cow's milk and casein-specific IgE levels were measured from serum samples by FEIA method using ImmunoCAP (Pharmacia) device and the level of $\geq 0.35 \mathrm{kUA} / \mathrm{L}$ was accepted as positive. Milk-specific IgE levels of $>15$ 
$\mathrm{kUA} / 1$ in children under 2 years old and $>5 \mathrm{kUA} / \mathrm{l}$ in children above 2 years old were considered to be high (9).

Oral food challenge test: As a routine practice, test procedure and risks were initially explained to the families then informed consent was obtained from all patients' parents. All patients were examined in Pediatric Allergy Policlinic before starting the test. Necessary preparations were made for possible emergency situations which may develop during the test. In healthy cases who had normal physical examination finding, cow's milk was administered in increasing amounts over 20 minutes intervals. The test was terminated when the objective symptoms had developed. If no reaction was seen during the test, parents were informed about late reactions such as GIS manifestations and eczema. Then, patients were discharged after 4-hour monitoring. Parents were asked to report any delayed reactions which may occur into 72 hours after the test.

\section{Statistical Analysis}

Results were assessed using SPSS for Windows 13.0 Statistics software. Categorical data were given as number and percentage; numerical data were expressed as mean \pm standard deviation (SD). Chisquare test was carried out to compare the categorical measurements. In independent samples, numerical data were compared using Student T-test when providing the assumptions or Mann-Whitney U test when not providing the assumptions. Mann-Whitney U-test was used to compare two independent groups, and Pearson chi-square test or Fisher's chi-square test was used to compare the categorical variables. Multivariate Logistic Regression analysis was used to determine which measurements can be used to ascertain the risk factor. $\mathrm{P}<0.05$ was considered statistically significant.

\section{Results}

Totally, 81 patients with CMA were included. Characteristics of patients are shown in Table 1. Fiftythree $(65 \%)$ of patients were male. For the whole study group, the mean follow-up duration was $19 \pm 10,8$ months, age at first symptom was $4 \pm 2,3$ months, breastfeeding duration was $15 \pm 7,8$ months, and age of the starting complementary foods was $5,4 \pm 0,8$ months. Family history was positive for atopy in 18 patients (22\%). 24 patients (30\%) had multiple food
Table 1. Characteristics of patients with cow's milk allergy

\begin{tabular}{|c|c|}
\hline & Results \\
\hline Total numbers of patients & 81 \\
\hline \multicolumn{2}{|l|}{ Gender } \\
\hline Male & $53(65)$ \\
\hline Follow-up duration (month) & $19 \pm 10.8$ \\
\hline Age at first symptom (month) & $4 \pm 2.3$ \\
\hline Breastfeeding duration (month) & $15 \pm 7.8$ \\
\hline $\begin{array}{l}\text { Age of the starting complementary foods } \\
\text { (month) }\end{array}$ & $5.4 \pm 0.8$ \\
\hline Positive family history ofatopy & $18(22)$ \\
\hline Multiple food allergy presence & $24(30)$ \\
\hline Egg & $23(28)$ \\
\hline Hazelnut & $3(3.7)$ \\
\hline Fish & $1(1.2)$ \\
\hline Concomitant allergic disease presence & $47(58)$ \\
\hline Asthma & $8(10)$ \\
\hline Rhinitis & $11(14)$ \\
\hline Atopic dermatitis & $31(38)$ \\
\hline Inhalant allergen sensitivity & $5(6)$ \\
\hline \multicolumn{2}{|l|}{ Clinical manifestations } \\
\hline Skin symptoms & $76(94)$ \\
\hline Urticaria & $63(78)$ \\
\hline Angioedema & $29(36)$ \\
\hline Atopic dermatitis & $31(38)$ \\
\hline Gastrointestinal system symptoms & $20(25)$ \\
\hline Vomiting & $11(14)$ \\
\hline Diarrhea & $4(5)$ \\
\hline Bloody stool & $8(10)$ \\
\hline Respiratory system symptoms & $15(18.5)$ \\
\hline Wheeze & $12(15)$ \\
\hline Dyspnea & $9(11)$ \\
\hline Rhinitis & $4(5)$ \\
\hline Anaphylaxis & $16(20)$ \\
\hline
\end{tabular}

allergies; egg was the most commonly observed food allergy which was seen in $23(28 \%)$ patients, hazelnut and fish allergies was determined in $3(3.7 \%)$ and 1 (1.2\%) patients, respectively. 47 of patients $(58 \%)$ had concomitant allergic disease including asthma in 8 patients (10\%), rhinitis in 11 patients (14\%) and atopic dermatitis in 31 patients (38\%). İn 5 patients, inhalant 
allergen sensitivity was observed (6.2\%), in which all were mite allergy.

Most frequently seen clinical manifestations were in skin, which was seen in 76 patients (94\%), 20 patients $(25 \%)$ had GIS symptoms and 15 (18.5\%) had respiratory symptoms. Anaphylaxis development following cow's milk protein intake was noted in 16 patients (20\%).

Complimentary food which caused the first allergic reaction was formula feed in 32 patients $(39.5 \%)$, yogurt in $25(31 \%)$ patients and milk pudding in 6 $(7.4 \%)$ patients. The allergic reaction was reported in 18 of patients (22\%) while breastfeeding.

Evaluation of Tolerance Development: Of 81 patients included the study, $53(65 \%)$ completed the 3-year follow-up period; cow's milk tolerance developed in 40 patients $(75 \%)$ but sensitivity was ongoing in 13 patients $(25 \%)$ at the end of the 3-year follow-up period. When we analyzed improvement rates by years, it was $41 \%(\mathrm{n}=22)$ within one year, $64 \%(n=34)$ within two years and $75 \%(n=40)$ within three years.

Comparison of characteristics between the patients acquired tolerance at the end of the 3-year follow-up and patients with persistent CMA is shown in Table 2 . Asthma was not seen in patients acquired tolerance, and it was seen in 5 patients $(38.5 \%)$ with persistent CMA $(\mathrm{p}<0.001)$. Inhalant allergen sensitivity was seen in one patient $(2.5 \%)$ acquired tolerance and in 3 patients $(23 \%)$ with persistent CMA. Inhalant allergen sensitivity was found to be statistically significant in patients with persistent CMA ( $\mathrm{p}=0.042)$. In patients with persistent CMA, there was urticaria/angioedema in $84.6 \%$, respiratory system symptoms in $61.5 \%$ and anaphylaxis in $77 \%$ of cases which were significantly higher compared to those in patients acquired tolerance $(\mathrm{p}<0.001)$.

Comparison of Laboratory Findings of Patients Becoming Tolerant: Table 3 shows a comparison of laboratory findings of patients at the time of diagnosis. At the diagnosis time, induration diameter during the skin prick test with cow's milk was above the predictive value in 3 patients $(8.6 \%)$ acquired tolerance and 11 patients $(92 \%)$ with persistent CMA $(\mathrm{p}<0.001)$. Total $\mathrm{IgE}$ level was found higher than normal range by age in 23 patients (59\%) acquired tolerance and in 10 patients (77\%) with persistent CMA ( $\mathrm{p}=0.328)$. Milk-specific
Table 2. Comparison of characteristics of patients with or without against cow's milk tolerance

\begin{tabular}{|c|c|c|c|}
\hline & \multicolumn{2}{|c|}{ Tolerance development } & \multirow[b]{2}{*}{$\mathrm{p}$} \\
\hline & $\begin{array}{l}\text { Yes } \\
(n=40) \\
n \%\end{array}$ & $\begin{array}{l}\text { No } \\
(\mathrm{n}=13) \\
\mathrm{n} \%\end{array}$ & \\
\hline Gender & & & 1.00 \\
\hline Male & $28(70)$ & $9(69)$ & \\
\hline $\begin{array}{l}\text { Age at first symptom } \\
\text { (month) }\end{array}$ & $4.4 \pm 2.6$ & $5 \pm 2$ & 0.570 \\
\hline $\begin{array}{l}\text { Breastfeeding duration } \\
\text { (month) }\end{array}$ & $13.6 \pm 7.5$ & $21 \pm 6.6$ & $<0.001$ \\
\hline $\begin{array}{l}\text { Positive family history } \\
\text { of atopy }\end{array}$ & $12(30)$ & $2(15.4)$ & 0.473 \\
\hline Multiple food allergy & $14(35)$ & $2(15.4)$ & 0.299 \\
\hline Concomitant diseases & $21(52.5)$ & $9(69)$ & 0.349 \\
\hline Asthma & $0(0)$ & $5(38.5)$ & $<0.001$ \\
\hline Rhinitis & $6(15)$ & $1(7.7)$ & 0.667 \\
\hline Atopic dermatitis & $15(37.5)$ & $2(15.4)$ & 0.183 \\
\hline $\begin{array}{l}\text { Inhalant allergen } \\
\text { sensitivity }\end{array}$ & $1(2.5)$ & $3(23)$ & 0.042 \\
\hline \multicolumn{4}{|l|}{$\begin{array}{l}\text { CMA Clinical } \\
\text { Manifestations }\end{array}$} \\
\hline Skin symptoms & $38(95)$ & $13(100)$ & 1.00 \\
\hline Urticaria & $34(85)$ & $12(92)$ & 0.667 \\
\hline Angioedema & $7(17.5)$ & $11(84.6)$ & $<0.001$ \\
\hline Atopic dermatitis & $15(37.5)$ & $2(15.4)$ & 0.183 \\
\hline $\begin{array}{l}\text { Respiratory system } \\
\text { symptoms }\end{array}$ & $3(7.5)$ & $8(61.5)$ & $<0.001$ \\
\hline Wheezing & $2(5)$ & $6(46)$ & 0.002 \\
\hline Dyspnea & 0 & $6(46)$ & $<0.001$ \\
\hline Rhinitis & 0 & $3(23)$ & 0.012 \\
\hline GIS symptoms & $7(17.5)$ & $6(46)$ & 0.061 \\
\hline Vomiting & $2(5)$ & $6(46)$ & 0.002 \\
\hline Diarrhea & $3(7.5)$ & 0 & 0.567 \\
\hline Bloody stool & $4(\% 10)$ & 0 & 0.561 \\
\hline Anaphylaxis & $4(10)$ & $10(77)$ & $<0.001$ \\
\hline
\end{tabular}

IgE level was $3,5 \pm 9 \mathrm{kUA} / \mathrm{L}$ in patients acquired tolerance and $51 \pm 37 \mathrm{kUA} / \mathrm{L}$ in patients with persistent CMA ( $<<0.001)$. Also, casein-specific IgE level was $1,8 \pm 7,5 \mathrm{kU} / \mathrm{L}$ in patients acquired tolerance and $28 \pm 27$ $\mathrm{kU} / \mathrm{L}$ in persistent CMA; it was significantly higher in patients with persistent CMA compared to the others $(\mathrm{p}<0.001)$. 
Table 3. Comparison of laboratory findings of patients with or without cow's milk tolerance

\begin{tabular}{|c|c|c|c|}
\hline & \multicolumn{2}{|c|}{ Tolerance development } & \multirow[b]{2}{*}{$\mathrm{p}$} \\
\hline & $\begin{array}{l}\text { Yes } \\
\mathrm{n} \%\end{array}$ & $\begin{array}{l}\text { No } \\
\text { n } \%\end{array}$ & \\
\hline $\begin{array}{l}\text { Cow's milk skin prick } \\
\text { test positivity test } \\
\text { positivity }\end{array}$ & $35(87.5)$ & $12(92)$ & 1 \\
\hline $\begin{array}{l}\text { Patients with prick test } \\
\text { induration diameter } \\
\text { higher than predictive } \\
\text { value }\end{array}$ & $3(8.6)$ & $11(92)$ & $<0.001$ \\
\hline Total IgE ( kU/L) & $116 \pm 122$ & $265 \pm 299$ & 0.046 \\
\hline $\begin{array}{l}\text { Patients with total } \mathrm{IgE} \\
\text { results higher than the } \\
\text { normal range }\end{array}$ & $23(59)$ & $10(77)$ & 0.328 \\
\hline $\begin{array}{l}\text { Milk-specific IgE } \\
\text { (kUA/L) }\end{array}$ & $3.5 \pm 9$ & $51 \pm 37$ & $<0.001$ \\
\hline $\begin{array}{l}\text { Patients with Milk- } \\
\text { specific IgE results } \\
\text { higher than the normal } \\
\text { range }\end{array}$ & $3(7.7)$ & $10(77)$ & $<0.001$ \\
\hline $\begin{array}{l}\text { Casein-specific IgE } \\
\text { (kUA/L) }\end{array}$ & $1.8 \pm 7.5$ & $28 \pm 27$ & $<0.001$ \\
\hline $\begin{array}{l}\text { Patients with Casein- } \\
\text { specific IgE results } \\
\text { higher than the normal } \\
\text { range }\end{array}$ & $1(3)$ & $10(77)$ & $<0.001$ \\
\hline
\end{tabular}

Multivariate Logistic Regression analysis was performed to determine the factors which affect the tolerance development to cow's milk (Table 4). It was found that higher milk-specific IgE level at the time of diagnosis is a risk factor for persistent CMA. It was determined that higher milk-specific IgE level increased 1.10-fold (95\% CI: 1,03-1,17; p=0.004) the persistent CMA risk as shown in Table 4.

\section{Discussion}

In the present study, $65 \%$ of patients were male. It has been reported that male gender is a risk factor for CMA during childhood and CMA is seen more commonly in males $(2,10-12)$. In accordance with the literature, a number of male cases were found higher in our study.

Positive family history of atopy is a known risk factor for the development of atopic diseases in children. In a study by Santos et al. (11) who assessed 139 patients with CMA, positive family history of
Table 4. Multivariate Logistic Regression Analysis of an independent risk factor for persistent cow's milk allergy

\begin{tabular}{llll}
\hline Measurements p & & $\begin{array}{l}\text { Odds Ratio } \\
\text { (OR) }\end{array}$ & $\begin{array}{l}95 \% \text { Confidence } \\
\text { Interval for OR }\end{array}$ \\
\hline Asthma presence & 0.010 & 1196.898 & $5.578-256825.25$ \\
Milk-specific IgE & 0.010 & 1.070 & $1.017-1.127$
\end{tabular}

atopy has been reported at the rate of $35 \%$. Dias et al. (13) have reported that $53 \%$ of patients $>2$ years old with CMA have a positive family history of atopy. The family history of atopy was positive in $22 \%$ of our patients.

Multiple food allergies were determined in 24 patients (30\%) with CMA in our study. Food allergy incidence may vary by age and geographic area. Skripak et al. (10) have reported that $91 \%$ of their cases were allergic to multiple foods coexisting egg (79\%), peanut $(73 \%)$, tree nut $(51 \%)$, soya $(41 \%)$ and wheat $(36 \%)$. In accordance with the literature, the most frequently coexisting second allergen was egg (28\%) which was seen in 23 patients in our study. The others were hazelnut in 3 patients $(3.7 \%)$ and fish in 1 patient $(1.2 \%)$.

Allergic diseases emerge within a chronological course which is also described as an allergic march. It has been reported that children with CMA have a risk for the development of atopic dermatitis during the early period of disease and asthma, allergic rhinitis and inhalant allergen sensitivity occurrence for forthcoming years $(10,11,14)$. In our study, the concomitant allergic disease was found in 47 patients (58\%). Of them, 8 (10\%) had asthma, $11(14 \%)$ had rhinitis and 31 had $(38 \%)$ atopic dermatitis. There was an inhalant allergen sensitivity in 5 patients (6\%). Saarinen et al. (14) prospectively followed 118 children with the diagnosis of CMA until they were 8.6-years-old. The authors have reported asthma in $25.8 \%$, rhinoconjunctivitis in $52.6 \%$, atopic dermatitis in $76.7 \%$ and inhalant allergen sensitivity in $59.5 \%$ of cases. Our results confirmed that most frequent coexisting disease is atopic dermatitis in the early period. In our study, asthma, allergic rhinitis, and inhalant allergen sensitivity rates were found lower than those in literature. It was thought that this inconsistency may be due to our relatively shorter follow-up period (1-43 months).

In our study, most commonly seen clinical manifestations were skin (urticaria, angioedema, 
atopic dermatitis) in 76 patients (94\%), GIS (vomiting, diarrhoea, bloody stool) in 20 patients $(24.7 \%)$ and respiratory system symptoms (wheezing, dyspnea, rhinitis) in 15 patients (18.5\%). Although CMA causes various clinical evidence, skin manifestations were most frequently reported in the literature $(11,13)$. Anaphylaxis was determined in 16 cases (20\%) in our study which were higher compared to those in the literature $(11,13)$. Because our institute is a tertiary hospital, patients with more severe clinical manifestations may be referred to us. Hence, the discrepancy may be a result of this situation.

Foods caused first allergic reaction were formula feed in 32 patients $(39.5 \%)$, yogurt in 25 cases $(31 \%)$ and milk pudding in 6 patients $(7.4 \%)$. First allergic reaction occurred in 18 of cases (22\%) during breastfeeding. In a previous study, triggering factors were formula feed, breast milk, yogurt, partially hydrolyzed feed and deeply hydrolized feed or cow's milk in $81 \%, 3.8 \%, 1.5 \%, 5.3 \% 0.8 \%$ of CMA cases, respectively (12). In accordance with the literature, formula feed was found to be the most common cause of first allergic reaction in our study.

In our study, tolerance developed in 40 of 53 patients $(75 \%)$ during the 3-year follow-up period. Improvement rates by years were $41 \%$ for the first year, $64 \%$ for the second year and $75 \%$ for the third year. It is known that most patients acquire tolerance to cow's milk until they are 3-year-old, and the prognosis is better $(12,15,16)$. In a previous cohort study, a total of 1749 neonatal were followed during 15 years and tolerance development has been reported in $56 \%$ of infants diagnosed with CMA within 1 year of appearance. The rate was $77 \%$ for the second year and $87 \%$ for the third year (7). In another study, tolerance rate was reported $19.8 \%$ for the fourth year, $42 \%$ for the eighth year (10). Also, Bishop et al. (17) reported the tolerance rates as $28 \%$ for the second year and $56 \%$ for the fourth year.

In our study, we aimed to compare the characteristics of cases acquired or not acquired tolerance. Seventy percent of patients acquired tolerance and 69\% of patients with persistent CMA were male. No sex difference was found for tolerance development in other studies $(11,18)$. Similarly, in accordance with the literature, we did not find any effect of gender distribution on tolerance development.

It has been reported that age at first symptom is not associated with persistent CMA $(11,19)$. We also found that age at first symptom did not differ between patients acquired tolerance or persistent CMA.

Breastfeeding duration was 15.5 months (range; 1-26 months) in patients acquired tolerance and 24 months (range; 7-25 months) in patients with persistent CMA ( $<<0.001)$. In a study by Vanto et al. (12), the authors have reported that breastfeeding duration is longer in cases with persistent CMA than patients acquired tolerance, and they have suggested that cellular cytokine and the other compounds in breast milk may be associated with persistent CMA. Suh et al. (19) have reported that breastfeeding duration has no effect on tolerance development in cases of atopic dermatitis and CMA. Although variable results have been reported in the literature, breastfeeding duration was longer in our cases with persistent CMA. We are considering that families continue to give breast milk for a long time believing that children are insufficiency nourished because of the elimination diet.

In the literature, positive family history of atopy has been reported to be a risk factor for persistent CMA $(11,13,18)$. In contrast, Goldber et al. (20) have suggested that atopy history reported by the families may be misleading, and it may be insufficient for predicting persistent CMA in children. Positive family history of atopy was not associated with persistent CMA in our study. It has been reported that a positive family history of atopy is an independent risk factor for the other allergic disorders and inhalant allergen sensitivity (11). Although there are different results in the literature, we suggest that considering the atopy which diagnosed by a physician is more accurate approach.

Multiple food allergies were determined in $35 \%$ of cases acquired tolerance and in $15.4 \%$ of cases with persistent CMA. In a previous study (10), it was found that allergy against to other foods remained in $18 \%$ of patients when they became 4-year-old even cases had acquired tolerance to cow's milk suggesting no effect of multiple food allergies on tolerance development. Santos et al. (11) have reported that presence of allergy against other foods is a risk factor for persistent CMA. Although there are different results in literature, we found no effect of multiple food allergies on tolerance development.

According to the literature, asthma prevalence is higher in children with persistent CMA (14-16, 21). Consistent with the literature, asthma presence 
was found higher in children with persistent CMA compared to children acquired tolerance in our study. Skpirak et al. (10) have suggested that the presence of asthma and rhinitis are associated with poor tolerance development. Santos et al. (11) have reported that the presence of asthma is a risk factor for persistent CMA.

In our study, angioedema was observed in $84.6 \%$, respiratory system symptoms in $61.5 \%$ and anaphylaxis in $77 \%$ of cases with persistent CMA which all were significantly higher than those in patients acquired tolerance. Santos et al. (11) reported significantly higher rates for skin manifestations, angioedema and respiratory system symptoms in patients with persistent CMA older than 2 years old compared to patients acquired tolerance smaller than 2 years old. Early respiratory symptoms as well as skin manifestations, and more severe disease at the time of diagnosis have been reported to be risk factor for persistent CMA (22). Similarly, angioedema, respiratory system manifestations and anaphylaxis were found higher in persistent CMA patients. We concluded that persistent CMA may result from more severe clinical manifestations at the early period of disease.

It is known that extended induration diameter during the prick test negatively influences the tolerance development and it is a risk factor for persistent CMA $(14,18)$. Santos et al. (11) found that induration diameter of $>10 \mathrm{~mm}$ was associated with delayed tolerance. In another study, induration diameter of $>5$ $\mathrm{mm}$ was associated with persistent CMA over fouryear-old (12). In our study, induration diameter of $\geq 8 \mathrm{~mm}$ for children smaller than 2 years old and $\geq 6$ $\mathrm{mm}$ for children older than 2 years old correlated with persistent CMA.

Milk-specific IgE value was found to be above the predictive level in $7.7 \%$ of patients acquired tolerance and in $77 \%$ of patients with persistent CMA in our study. It is known that increased milk-specific $\operatorname{IgE}$ level has a negative effect on tolerance development and it is a risk factor for persistent CMA (10-12,15,2325). Consistently, increased milk-specific IgE level was a risk factor for persistent CMA in our study. In a study by Chatchatee et al. (26), increased caseinspecific IgE level was found to be associated with persistent CMA independently of patient's age. In our study, casein-specific IgE levels were significantly higher in patients with persistent CMA.

\section{Conclusion}

In conclusion, clinical parameters and allergy test results may help to predict the prognosis of CMA. Children with CMA should be followed for the development of the other atopic disorders. Novel studies are needed to establish risk factors for tolerance development or persistence in CMA.

\section{Ethics}

Ethics Committee Approval: Ethics committee approval was obtained from Bursa Uludag University Local Ethics Committee.

Conflict of Interest: No conflict of interest was declared by the authors.

Financial Disclosure: The authors declared that this study received no financial support.

\section{References}

1. Fiocchi A, Brozek J, Schunemann H, Bahna SL, von Berg A, Beyer K, et al. World Allergy Organization (WAO) Diagnosis and Rationale for Action against Cow's Milk Allergy (DRACMA) Guidelines. Pediatr Allergy Immunol 2010;21:1-125.

2. Sicherer $\mathrm{CH}$, Sampson HA. Food allergy: Epidemiology, pathogenesis, diagnosis, and treatment. J Allergy Clin Immunol 2014;133:291-307.

3. Altıntaş D, Güneşer N, Evliyaoğlu N. A prospectivestudy of cow's milk allergy İN Turkish infants. Acta Paediatr 1995;84:1320-1.

4. NIAID-Sponsored Expert Panel, Boyce JA, Assa'ad A, Burks AW, Jones SM, Sampson HA, et al. Guidelines fort the Diagnosis and Management of Food Allergy in the United States; Report of the NIAID- Sponsored Expert Panel. J Allergy Clin Immunol 2010;126:51-8.

5. Mansoor DK, Sharma HP. Clinical Presentations of Food Allergy. Pediatr Clin N Am 2011;58:315-26.

6. Spergel JM, Paller AS. Atopic dermatitis and the atopic march. J Allergy Clin Immuno 2003;112:118-27.

7. Fiocchi A, Terracciano L, Bouygue GR, Veglia F, Sarratud T, Martelli A, et al. Incremental prognostic factors associated with cow's milk allergy outcomes in infant and child referrals: the Milan Cow's Milk Allergy Cohort Study. Ann Allergy Asthma Immunol 2008;101:166-73.

8. Smith HP, Ownby RD. Clinical significance of immunoglobulin E. Middleton's Allergy: Principles and Practice: 7th edition; 2009.

9. Smith HP, Ownby RD. Clinical significance of immunoglobulin E. Middleton's Allergy: Principles and Practice: 7th edition; 2009.

10. Skripak JM, Matsui EC, Mudd K, Wood RA. The natural history of IgE-mediated cow's milk allergy. J Allergy Clin Immunol 2007;120:1172-7.

11. Santos A, Dias A, Pinheiro JA. Predictive factors for the persistence of cow's milk Allergy. Pediatr Allergy Immunol 2010;21:1127-34.

12. Vanto T, Helppila S, Juntunen-Backman K, Kalimo K, Klemola $\mathrm{T}$, Korpela R, et al. Prediction of the development of tolerance 
to milk in children with cow's milk hypersensitivity. J Pediatr 2004;144:218-22.

13. Dias A, Santos A, Pinheiro JA. Persistence of cow's milk allergy beyond two years of age. Allergol Immunopathol 2010;38:8-12.

14. Host A, Halken S, Jacobsen HP, Christensen AE, Herskind AM, Plesner K. Clinical course of cow's milk protein allergy/ intolerance and atopic diseases in childhood. Pediatr Allergy Immunol 2002;13:23-8.

15. Saarinen KM, Pelkonen AS, Makela MJ, Savilahti E. Clinical course and prognosis of cow's milk allergy are dependent on milk-specific IgE status. J Allergy Clin Immunol 2005;116:86975.

16. Host A, Halken S. A prospective study of cow milk allergy in Danish infants during the first 3 years of life. Clinical course in relation to clinical and immunological type of hypersensitivity reaction. Allergy 1990;45:587-96.

17. Bishop JM, Hill DJ, Hosking CS. Natural history of cow milk allergy: clinical outcome. J Pediatr 1990;116:862-7.

18. Elizur A, Rjuan N, Micheal R, Goldbeg Leshno M, Cohen A, Katz Y. Natural Course and Risk Factors for Persistence Ig E Mediated Cow's Milk Allergy The Journal Of Pediatrics 2012;161:482-7.

19. Suh J, Lee H, Lee JH, Cho J, Yu JS, Kim J, et al. Natural Course Cow's milk Allergy in Children Atopik Dermatitis. The Korean Academy of Medical Sciences 2011;26:1152-8.

20. Goldber M, Eisenberg E, Elizur A. Role of parental atopy in cow's milk allergy: a population-based study. Ann Allergy Asthma Immunol 2013;110:279-83.
21. Sampaio G, Marinho S, Prates S, Morais-Almeida M, RosadoPinto J. Transient vs persistent cow's milk allergy and development of other allergic diseases. Allergy 2005;60:411-2.

22. Fiocchi A, Schünemann HJ, Brozek J, Restani P, Beyer $\mathrm{K}$, Troncone R, et al. Diagnosis and Rationale for Action Against Cow's Milk Allergy (DRACMA): a summary report 2010;126:1119-28.

23. Sicherer SH, Sampson HA. Cow's milk protein-specific IgE concentrations in two age groups of milk-allergic children and in children achieving clinical tolerance. Clin Exp Allergy 1999;29:507-12.

24. Hill DJ, Firer MA, Ball G, Hosking CS. Natural history of cows' milk allergy in children: immunological outcome over 2 years. Clin Exp Allergy 1993;23:124-31.

25. Garcia-Ara MC, Boyano-Martinez MT, Diaz-Pena JM, Martin-Munoz MF, Martin-Esteban M. Cow's milk-specific immunoglobulin $\mathrm{E}$ levels as predictors of clinical reactivity in the follow-up of the cow's milk allergy infants. Clin Exp Allergy 2004;34:866-70.

26. Chatchatee P, Jarvinen KM, Bardina L, Beyer K, Sampson HA. Identification of IgE-and Ig G binding epitopes on alpha (s1)casein: differences in patients with persistent and transient cow's milk allergy. J Allergy Clin Immunol 2001;107:379-83. 